\title{
Analysis of Communication Skills in Class IV Elementary School Students in Learning Entrepreneurship Through SRBP Models in SDN 3 Krakal
}

\section{Lin Wahyuni, Kartika Christy Suryandari}

Universitas Sebelas Maret

linwahyuni177@gmai.com

\section{Article History}

accepted 24/09/2019

\begin{abstract}
Analysis of Communication Skills of Grade IV Elementary Students in Learning Entrepreneurship through the SRBP Model in SD N 3 Krakal. This study aims to analyze the communication skills of fourth grade students in Entrepreneurship learning through the SRBP (Scientific Reading Based Project) model or scientific project literacy based learning model at SD N 3 Krakal, Kebumen Regency. The method of data analysis is done by qualitative descriptive analysis. Data retrieval is done by using observation, interview and documentation techniques. The population in this study were students of class IV SD N 3 Krakal, totaling 20 students. The results show that students of grade IV SD N 3 Krakal have a high level of communication skills, both towards the teacher, peers and other people around him. However, some students still have low communication skills, as evidenced when learning he/she just tends to be quiet and shame to argue.
\end{abstract}

Keywords: Communication Skills, Entrepreneurship Learning, SRBP Learning Model

\begin{abstract}
Abstrak
Analisis Keterampilan Berkomunikasi Siswa Kelas IV SD Dalam Pembelajaran Kewirausahaan Melalui Model SRBP di SD N 3 Krakal. Penelitian ini bertujuan untuk menganalisis keterampilan berkomunikasi siswa kelas IV dalam pembelajaran Kewirausahaan melalui model SRBP (Scientific Reading Based Project) atau model pembelajaran berbasis literasi proyek ilmiah di SD N 3 Krakal Kabupaten Kebumen. Metode analisis data dilakukan dengan analisis deskriptif kualitatif. Pengambilan data dilakukan dengan menggunakan teknik observasi, wawancara dan dokumentasi. Populasi dalam penelitian ini adalah siswa kelas IV SD N 3 Krakal yang berjumlah 20 siswa. Hasil menunjukkan bahwa siswa kelas IV SD N 3 Krakal memiliki tingkat keterampilan berkomunikasi yang baik, terhadap guru, teman sebaya dan orang lain di sekitarnya. Namun,beberapa siswa masih memiliki keterampilan berkomunikasi yang rendah, terbukti saat pembelajaran ia hanya cenderung diam dan malu untuk berpendapat.

Kata kunci: Keterampilan Berkomunikasi, Pembelajaran Kewirausahaan, Model Pembelajaran SRBP
\end{abstract}

Social, Humanities, and Education Studies (SHEs): Conference Series https://jurnal.uns.ac.id/shes

p-ISSN 2620-9284

e-ISSN 2620-9292 


\section{PENDAHULUAN}

Komunikasi tidak dapat dipisahkan dalam proses pembelajaran, karena proses pembelajaran terjadi akibat adanya komunikasi, baik itu yang bersifat intrapersonal seperti berpikir, mengingat, serta melakukan persepsi, maupun secara interpersonal yaitu melalui proses penyaluran ide atau gagasan informasi kepada orang lain, menghargai pendapat orang lain, serta menyimak argumentasi yang disampaikan oleh orang lain (Mulyana, 2014). Kemampuan berkomunikasi menjadi syarat penting dalam proses pembelajaran karena dapat membantu dan memfasilitasi peserta didik untuk mengutarakan gagasan, serta bertukar informasi dengan guru atau sesama peserta didik.

Komunikasi merupakan alat untuk membina hubungan sebagai implementasi dari kodrat manusia sebagai makhluk sosial. Komunikasi merupakan proses individu dalam hubungan, kelompok, organisasi, dan masyarakat membuat dan menggunakan informasi untuk berhubungan satu sama lain dengan lingkungan. Komunikasi merupakan sarana menampilkan pesan, mengekspresikan diri, serta mempengaruhi orang lain.

Pada konteks pembelajaran, keterampilan dalam berkomunikasi dapat dimaknai sebagai keterampilan yang harus dimiliki dan dikuasai oleh seorang peserta didik karena keterampilan ini bertujuan untuk menggali pengetahuan sebanyak-banyaknya serta untuk menyampaikan informasi kepada masyarakat baik secara lisan maupun tulisan. Komunikasi dalam pembelajaran akan membuat kegiatan pembelajaran menjadi lebih efektif karena terbangun komunikasi antara guru dengan peserta didik, ataupun diantara sesama peserta didik sehingga tujuan pembelajaran dapat tercapai (Iriantara, 2014).

Berkaitan dengan pembelajaran model SRBP, keterampilan komunikasi ini sangat diperlukan karena peserta didik akan menjadi narasumber yang harus menyampaikan materi yang dikuasainya ke dalam kelompok. Pembelajaran model SRBP akan membantu peserta didik untuk bekerjasama dalam kelompok serta mengajarkan berbagai keterampilan yang diperlukan bagi kehidupan mereka kelak seperti keterampilan berwirausaha.

Keterampilan komunikasi merupakan salah satu keterampilan sosial yang harus dikuasai dalam pembelajaran kewirausahaan selain kompetensi pengetahuan, keterampilan, serta nilai dan sikap. Oleh karena itu, komunikasi yang berlangsung dalam proses pembelajaran bukan sekedar bagaimana seorang guru menyampaikan bahan ajarnya, tetapi dilakukan untuk mengembangkan peserta didik menjadi seorang pribadi yang utuh, seperti menyelesaikan permasalahan bersama-sama dalam kelompok serta menumbuhkan semangat saling membelajarkan diantara sesama peserta didik.

Keterampilan berkomunikasi peserta didik juga akan memberikan suasana yang mendukung pembelajaran aktif dimana peserta didik memiliki kepercayaan diri dalam mengemukakan argumentasinya dan menjadi sarana dalam mengembangkan sikap empati dalam menghargai perbedaan pendapat yang akan mereka temukan dalam lingkungan masyarakat. Berkaitan dengan hal ini, pembelajaran kewirausahaan memiliki kedudukan yang sangat penting untuk dapat membekali peserta didik dengan berbagai keterampilan, termasuk keterampilan berkomunikasi sehingga proses belajar yang dilakukan dapat menjadi peserta didik sebagai generasi yang santun dalam bertutur kata, memiliki kepercayaan diri serta bersikap kritis, bersikap toleran terhadap segala perbedaan pendapat, menghargai pendapat orang lain sehingga mereka siap bersaing dalam era revolusi industri 4.0.

Model Scientific Reading Based Project (SRBP) adalah model pembelajaran menggunakan proyek dan riset dalam proses pembelajarannya dan berbasis aktivitas scientific reading (2019). SRBP telah diuji secara empiris berdasarkan kelebihan dan kelemahan yang dari perpaduan model Project Based Learning (PBL) dan Preview 
Question Reading Reflect Recite Review (PQ4R). Model pembelajaran SRBP didasari filosofi konstruktivisme yang mencakup empat aspek, yaitu pembelajaran yang membangun pemahaman peserta didik, pembelajaran dengan mengembangkan prior knowledge, pembelajaran yang merupakan proses interaksi social dan pembelajaran bermakna yang dicapai melalui pengalaman nyata.

Dalam model pembelajaran SRBP merupakan sistem pengetahuan yang mengkaitkan pengetahuan dari membaca/scientific reading dan pengalaman yang diwujudkan dalam sebuah proyek. Pengetahuan tersebut diperoleh manusia melalui akal dan panca indera dengan berbagai metode. Model SRBP memberikan dampak positif pada pembelajaran kewirausahaan. Nilai-nilai yang dapat diadopsi dari penerapan model SRBP antara lain mengembangkan keterampilan kristis dan kreatif, kemampuan berkolaboratif dalam menyelesaikan masalah, kemampuan berkomunikasi, meningkatkan minat membaca dan menstimulasi jiwa enterpreneurship.

\section{METODE}

Pendekatan penelitian ini adalah pendekatan kualitatif dan jenis penelitian yang bersifat deskriptif. Subjek dalam penelitian ini adalah 1 orang guru dan siswa kelas IV SD Negeri 3 Krakal yang berjumlah 20 orang yang terdiri dari 7 siswa perempuan dan 13 siswa laki-laki. Penelitian ini dilaksanakan di SD Negeri 3 Krakal pada semester ganjil tahun ajaran 2018/2019. Pengumpulan data dengan teknik observasi, angket, dan wawancara guru kelas. Teknik analisis data menggunakan Teknik Triangulasi dimana dalam teknik ini pengumpulan data bersifat penggabungan dari berbagai teknik dan menggunakan tiga langkah pengolahan data, yakni reduksi, menyajikan data, dan mengambil kesimpulan (Sugiyono, 2010: 330).Data dianalisis dengan rumus sebagai berikut:

Skor $=\frac{\text { Jumlah Skor }}{\text { Skor Maksimal }} \times 100 \%$

Rumus ini bisa digunakan untuk mengkonversikan jawaban dari data yang telah dihitung. Adapun skalanya menurut Riduwan, (2012:89) sebagai berikut:

\begin{tabular}{ll}
\hline \multicolumn{2}{c}{ SKALA PROSENTASE DATA } \\
\hline PROSENTASE & KETERANGAN \\
$86 \%-100 \%$ & Sangat Baik \\
$76 \%-85 \%$ & Baik \\
$60 \%-75 \%$ & Cukup Baik \\
$55 \%-59 \%$ & Kurang Baik \\
$<54 \%$ & Kurang Sekali \\
\hline
\end{tabular}

Tabel 1 Skala Prosentase Data

Selain itu, data kualitatif yang lain dalam penelitian ini diperoleh dari wawancara guru yang digunakan untuk mempertegas jawaban instrumen observasi kemudian dideskripsikan dalam pembahasan.

\section{HASIL DAN PEMBAHASAN}

Observasi aktivitas kemandirian siswa dalam proses pembelajaran dilaksanakan selama kegiatan pembelajaran berlangsung. Berdasarkan hasil penelitian yang telah dilaksanakan pada SD N 3 Krakal diperoleh bahwa keterampilan komunikasi dalam pembelajaran kewirausahaan dinilai dari aspek keterbukaan, sikap mendukung, empati, sikap positif dan keterbukaan. Data dalam penelitian dideskripsikan dalam diagram batang yang didapatkan dari angket dan instrumen observasi yang diperkuat dengan wawancara. 
Hasil Penelitian Menggunakan Angket

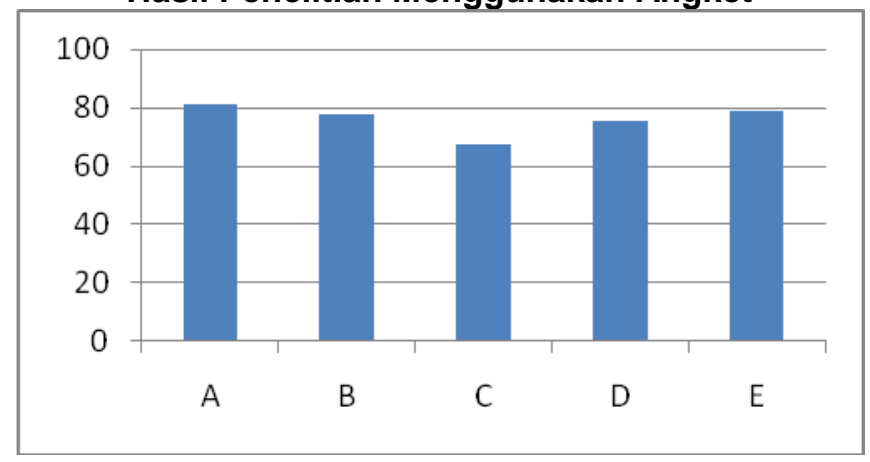

\section{Gambar 1. Profil Keterampilan Komunikasi Siswa dalam pembelajaran kewirausahaan} kelas IV menggunakan angket

Pada indikator keterbukaan yang terdiri aspek melakukan aktivitas bersama teman dan dapat menerima masukan atau saran dari teman. Dari perhitungan data menggunakan angket menunjukkan prosentase 81,25\%. Dengan demikian keterampilan komunikasi pada indikator keterbukaan siswa berada pada kriteria baik. Setiap aspek sudah menunjukkan pada kategori baik.

Pada indikator empati yang terdiri aspek memberikan ucapan selamat kepada teman yang berprestasi, menghargai pendapat teman dan dapat memberikan semangat kepada teman. Dari perhitungan data menggunakan angket menunjukkan prosentase $77,916 \%$. Dengan demikian tingkat keterampilan komunikasi siswa pada indikator empati berada pada kriteria baik. Setiap aspek sudah menunjukkan pada kategori baik .

Pada indikator sikap mendukung yang terdiri aspek mengingatkan teman, menghargai pendapat saat berdiskusi dan menghargai perbedaan sifat masingmasing individu. Dari perhitungan data menggunakan angket menunjukkan prosentase $67 \%$. Dengan demikian tingkat keterampilan komunikasi siswa pada indikator sikap mendukung berada pada kriteria cukup baik. Setiap aspek sudah menunjukkan pada kategori cukup baik.

Pada indikator sikap positif yang terdiri aspek berani bertanya, senantiasa berprasangka baik dan dapat berdiskusi dengan teman. Dari perhitungan data menggunakan angket menunjukkan prosentase 75\%. Dengan demikian tingkat keterampilan komunikasi siswa pada indikator sikap positif berada pada kriteria cukup baik. Setiap aspek sudah menunjukkan pada kategori cukup baik .

Pada indikator kesetaraan yang terdiri aspek senantiasa aktif terlibat dalam kegiatan di kelas, memberikan pendapat ketika berdiskusi, mengerjakan tugasnya dalam konteks kelompok dan bersifat terbuka pada orang lain. Dari perhitungandata menggunakan angket menunjukkan prosentase $78,75 \%$. Dengan demikian tingkat keterampilan komunikasi siswa pada indikator kesetaraan berada pada kriteria baik.

Berdasarkan data tersebut dapat dideskripsikan bahwa yang berada pada kategori baik adalah keterbukaan, sikap empati dan kesetaraan dalam pembelajaran. Sedangkan pada kategori cukup baik adalah pada aspek empati, sikap mendukung dan sikap positif.Keterampilan komunikasi siswa kelas IV di SD Negeri 3 Krakal sudah menunjukkan pada ranah baik. Siswa telah dapat melakukan aktivitas bersama teman-teman di kelompoknya serta dapat menerima saran dari rekan sekelompoknya pada saat pembelajaran kewirausahaan dengan model SRBP.

Keterampilan berkomunikasi siswa juga terlihat baik saat mereka mengerjakan proyek bersama membuat produk dengan potensi lokal yaitu jenitri, 
siswa sudah bisa membagi masing-masing tugas individu dan terdapat komunikasi selama kegiatan kelompok. Sedangkan pada kategori cukup terdapat pada menghargai masukan dari teman, menghargai sifat masing-masing individu dan bertanya pada guru tentang hal yang belum dimengerti. Siswa masih belum berani bertanya kepada guru tentang suatu hal yang belum dimengerti, siswa lebih senang bertanya kepada temannya tentang hal yang masih belum dipahaminya. Sehingga kemampuan keberanian untuk berbicara dan bertanya ini perlu ditingkatkan agar tidak terjadi kesalahpahaman kedepannya.

Kurangnya keterampilan komunikasi secara langsung perlu memperoleh perhatian khusus dari semua pihak di sekolah salah satunya bantuan dari seorang konselor. Sebagai mana yang dilansir peraturan pemerintah No.29 tahun 1990 (Setyoningtyas, 2014, hlm. 31) menyatakan tugas konselor atau guru pembimbing adalah membantu siswa untuk menemukan pribadi, mengenal Vivit Puspita Dewi: Meningkatkan Keterampilan Komunikasi Interpersonal Pada Siswa Yang Memiliki Kecenderungan Adiksi 107 lingkungan, dan perencanaan masa depan. Dalam hal ini konselor di sekolah dasar adalah guru kelas, oleh karenanya guru kelas harus memberikan perhatian lebih terutama untuk peserta didik yang keterampilan berkomunikasinya masih dalam taraf rendah atau kurang.

\section{SIMPULAN}

Berdasarkan hasil penelitian dan pembahasan maka dapat disimpulkan bahwa keterampilan berkomunikasi siswa pada pembelajaran kewirausahaan dengan model SRBP kelas IV SD Negeri 3 Krakal berada pada kriteria "baik" meskipun terdapat beberapa siswa yang masih ragu untuk mengaluarkan pendapatnya dan hanya diam.

Dalam mengembangkan keterampilan berkomunikasi siswa, hendaknya guru mampu meningkatkan semua aspek berkomunikasi, khususnya pada aspek sikap mendukung dan sikap positif yang mana siswa hanya akan berkomunikasi pada orang yang sudah dikenalnya lama dan cenderung malu kepada orang asing atau orang yang belum dikenalnya. Pengembangan keterampilan berkomunikasi siswa dapat dilakukan dengan memotivasi siswa agar dapat mengeluarkan pendapat atau isi hatinya serta guru memberikan respon untuk siswa yang berani mengeluarkan pendapatnya

\section{DAFTAR PUSTAKA}

Andrani, dkk. (2013). METODE PENELITIAN. Banten: Penerbit Universitas Terbuka Iriantara, Y. (2014). Komunikasi Pembelajaran. Bandung: Simbiosa Rekatama Media Marfuah. (2017). Meningkatkan Keterampilan Komunikasi Peserta Didik Melalui Model Pembelajaran Kooperatif Jigsaw. Jurnal Ekonomi Koperasi, Universitas Negeri Jakarta, Volume 26, Halaman 148-149, e-ISSN : 2540-7694

Mulyana, D. (2014). Komunikasi Pembelajaran. Bandung: Remaja Rosdakarya

Riduwan. (2012). Belajar Mudah Penelitian Untuk Guru, Karyawan, Peneliti, Pemula. Bandung: Alfabeta

Setyoningtyas, R. (2014). Persepsi guru bk tentang kompetensi konselor di sekolah dasar swasta kota semarang. Skripsi. UNNES

Suryandari, K.C; Sajidan; Rahardjo, S.B; dan Prasetyo, S.K. (2019). MODEL SCIENTIFIC READING BASED PROJECT (SRBP). Salatiga: Widya Sari Press

Zuhara, Evi. (2014). EFEKTIVITAS TEKNIK SOSIODRAMA UNTUK MENINGKATKAN KOMUNIKASI INTERNASIONAL SISWA. Jurnal Universitas Pendidikan Indonesia, respository.upi.edu 